\title{
PHENOLOGICAL OBSERVATIONS OF CALLERY PEAR (PYRUS CALLERYANA DECNE.) GROWING IN THE GREEN AREAS OF POZNAŃ
}

\author{
Leszek Bednorz, Anna Kowalska, Natalia Grygier, Urszula Kufel
}

L. Bednorz, A. Kowalska, N. Grygier, U. Kufel, Department of Botany, Poznań University of Life Sciences, Wojska Polskiego 71 C, 60-625 Poznań, Poland, e-mail: lbednorz@up.poznan.pl

(Received: June 30, 2015. Accepted: August 1, 2015)

\begin{abstract}
AвSTRACT. This paper presents the results of 3-year phenological observations of Callery pear (Pyrus calleryana) trees growing in green areas in the city of Poznań. The study was carried out in the years 2010, 2012 and 2013 at four localities of the species representing two cultivars of Callery pear: 'Chanticleer' and 'Capital'. The observations included the course of leaf development, leaf colouration and leaf fall, as well as fruit ripening and fall. Sixteen phenophases were taken into account. The observed trees were characterised by a long vegetation season lasting for approx. seven months, plentiful flowering lasting on average 15-19 days, attractive autumn leaf colouration and an exceptionally long period of leaf remaining on trees - even to the end of November. Fruits were noted on the trees only in 2013. The differences in timing and duration of Callery pear phenophases from year to year, between sites and cultivars are pointed out and discussed.
\end{abstract}

KeY WoRds: phenology, green areas, trees, Pyrus calleryana, Callery pear

\section{INTRODUCTION}

Callery pear Pyrus calleryana Decne. (Rosaceae) comes from eastern Asia and its specimens in natural localities reach 15-20 $\mathrm{m}$ in height (Culley \& HARDIMAN 2007). It is a species of a considerable decorative value and tolerating urban conditions well (FrazIK-AdAmczYK 2004, BorowsKi 2012). Numerous cultivars of the Callery pear are grown, differing slightly in habit, decorative value and frost resistance (BugaŁa 1991, FraziK-AdamczyK 2004, Latocha 2006, Łysiak 2006, Culley \& Hardiman 2007, CZEKAlski 2010). In Europe and in Poland the most common is cv. 'Chanticleer', a relatively low tree with a pyramid-shaped crown, growing mainly along streets. Callery pear started to be planted in Poland only recently, since the early 2000's (SwoczyNA et al. 2008, BEDNORz et al. 2013). Specimens of this species are particularly attractive in the period of flowering and in the autumn, when leaves are coloured orange and purple.

The aim of phenological observations is to determine the seasonal rhythm of plants and in the case of alien species, also their adaptability to local conditions. The dates of onset and the duration of individual phenological phases are dependent on climatic and habitat conditions, competition with other plants and obviously the rhythm specific to individual plant species.

The aim of this study was to present results of phenological observations of Callery pear (Pyrus calleryana) trees representing two cultivars: 'Chanticleer' and 'Capital', growing in Poznań, in terms of their suitability for urban green areas. To date no phenological observations of Callery pear have been conducted in Poland.

\section{MATERIAL AND METHODS}

Phenological observations of Callery pear trees were conducted in the years 2010, 2012 and 2013 at four localities in the following streets in the city of Poznań: Stróżyńskiego and Podgórna - cv. 'Chanticleer'; Murawa and Szylinga - cv. 'Capital'. Five trees were selected for observations in each locality. These observations included the course of leaf development, autumn leaf colouration and leaf fall, as well as flowering and fruit ripening and fall.

Phenophases were adopted after MEIER (2004) (numbers) and the Phenological Observation Guide of the IPG (http://www.agrar.hu-berlin.de/fakultaet/ 


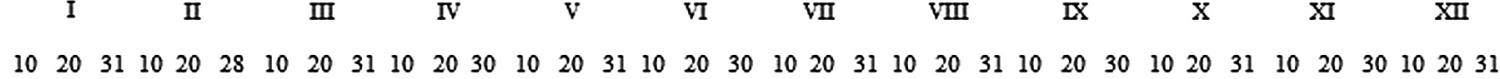

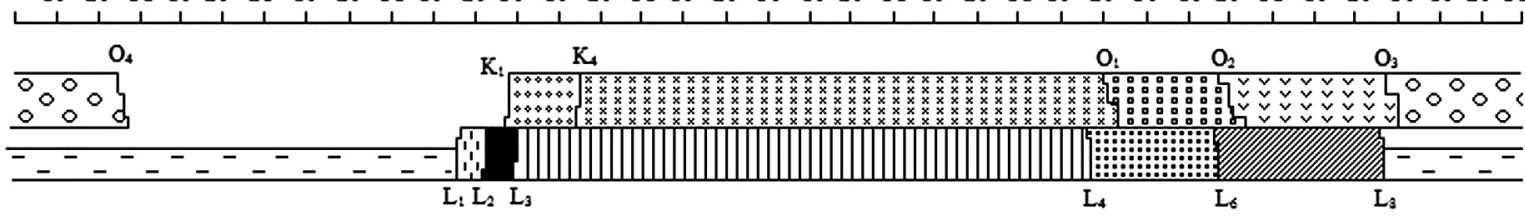

\begin{tabular}{|c|c|c|c|}
\hline-- & winter dormancy & {$\left[\begin{array}{lllll}0 & 0 & : & : \\
0 & \vdots & 0 & : & : \\
0 & 0 & : & : & :\end{array}\right]$} & flowering \\
\hline 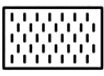 & $\begin{array}{l}\text { bod loosening and } \\
\text { opening }\end{array}$ & 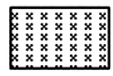 & unripe froit \\
\hline & leaf development & 물 & froti ripening \\
\hline & green leaves & 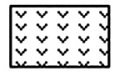 & ripe froit \\
\hline 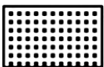 & $\begin{array}{l}\text { autumn leaf } \\
\text { colouration }\end{array}$ & $0_{0}^{0} 0_{0}^{0}$ & fruit fall \\
\hline
\end{tabular}

leaf fall

Fig. 1. Way of presentation of phenophases (explanations to Figure 4)

departments/dntw/agrarmet/phaenologie/ipg/IPG ObsGuide.pdf), with slight modifications.

The following phenological phases were observed: $1_{1}(07)$ - beginning of bud burst (a green leaf part is visible at the bud tip),

$1_{2}(11)$ - beginning of leaf development (the first, unfolded leaf blades are visible in several (3-4) places in the tree crown),

$1_{3}$ - full leaf development (over 50\% leaves in the tree crown are unfolded),

$1_{4}$ (92) - beginning of autumn leaf colouration (the first leaves, visible in several (3-4) places in the tree crown changed colour),

$1_{5}$ (95) - full leaf colouration (over $50 \%$ leaves in the tree crown changed colour),

$1_{6}$ (93) - beginning of leaf fall (approx. 5\% leaves fell from the tree crown),

$1_{7}$ (IPG) - full leaf fall (over $50 \%$ leaves fell from the tree crown),

$1_{8}(97)$ - end of leaf fall (approx. 95\% leaves fell from the tree crown),

$\mathrm{k}_{1}(60)$ - the first open flowers (the first open flowers in several (3-4) places in the tree crown),

$\mathrm{k}_{2}(61)$ - beginning of flowering (approx. 10\% flowers in the tree crown in bloom),

$\mathrm{k}_{3}(65)$ - full flowering (at least 50\% flowers in the tree crown in bloom),

$\mathrm{k}_{4}(69)$ - the end of flowering (approx. 95\% flowers in the tree crown out of bloom),

$\mathrm{o}_{1}(81)$ - beginning of fruit ripening (the first, ripe (coloured and soft) fruits visible in several (3-4) places in the tree crown),
$\mathrm{O}_{2}$ (85) - full fruit ripening (over $50 \%$ fruits have the characteristic colour of ripe fruits),

$\mathrm{O}_{3}$ - beginning of fruit fall (over 10\% fruits fell from the tree crown),

$\mathrm{O}_{4}$ - the end of fruit fall (approx. 10\% fruits remained in the tree crown or all fruits fell).

Results of phenological observations are presented in Table 1 and composite phenograms for all analysed trees are given in Figure 4. The method of phenophase presentation is shown in Figure 1.

Meteorological data from the years of observations came from the Poznań-Ławica weather station of the Institute of Meteorology and Water Management and multiannual data were collected from a study by Woś (2010).

\section{INFORMATION CONCERNING CERTAIN WEATHER ASPECTS IN THE YEARS OF ANALYSES}

Since weather factors may affect the course of the seasonal rhythm in plants, air temperature and precipitation were analysed in the years of observations, i.e. 2010, 2012 and 2013 in relation to the multiannual data from 1951-2000 (Figs 2, 3).

Mean diurnal temperature in all the months of 2010 was lower than the multiannual means. In contrast, in 2012-2013 mean annual temperature was higher than the multiannual mean. Differences resulted first of all from higher temperatures in the summer months. The year 2013 was exceptional due 

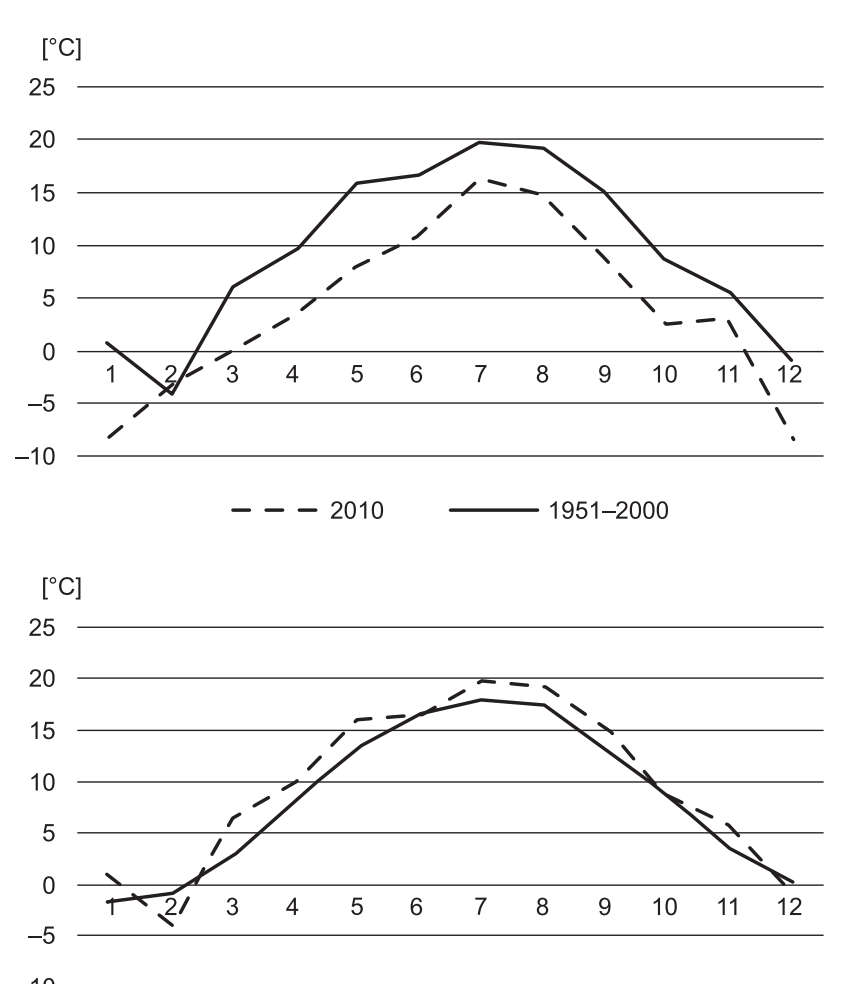

$-10$

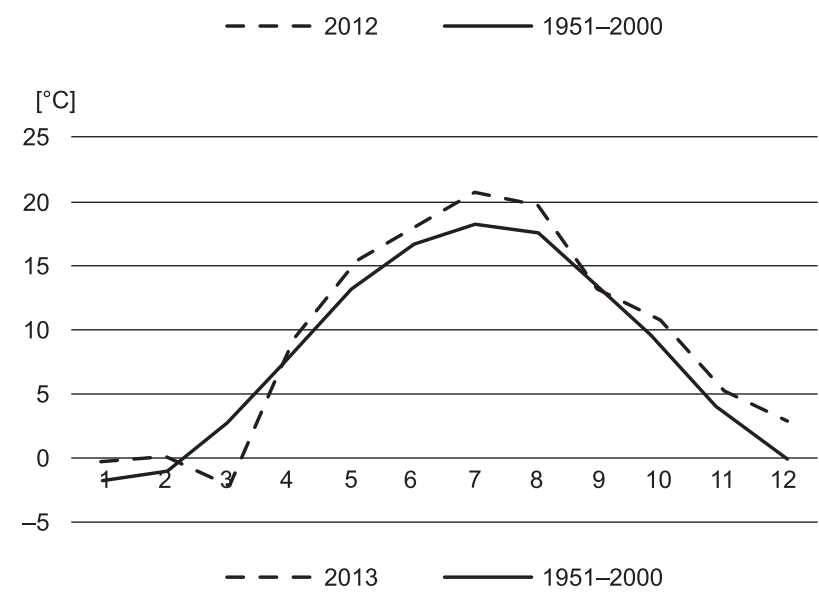

Fig. 2. Mean temperature per day $\left({ }^{\circ} \mathrm{C}\right)$ - Poznań-Ławica

to its very cold March, which resulted in a delay in the onset of vegetation in this plant species.

Annual precipitation totals in all years of analyses were higher than the precipitation mean for the multiannual period. The highest precipitation levels were recorded in 2010, with record high precipitation in August, amounting to $156 \mathrm{~mm}$. Also 2012 was the year of high precipitation, particularly in June and July, i.e. the first half of the summer.

\section{RESULTS}

It results from observations conducted over several years at four localities in Poznan that the beginning of the vegetation cycle for Callery pear trees, which is defined by the loosening and opening of buds, i.e. bud burst (phase $1_{1}$ ), lasts from 19 March to 20 April (Table 1). A marked delay was observed in 2013 as

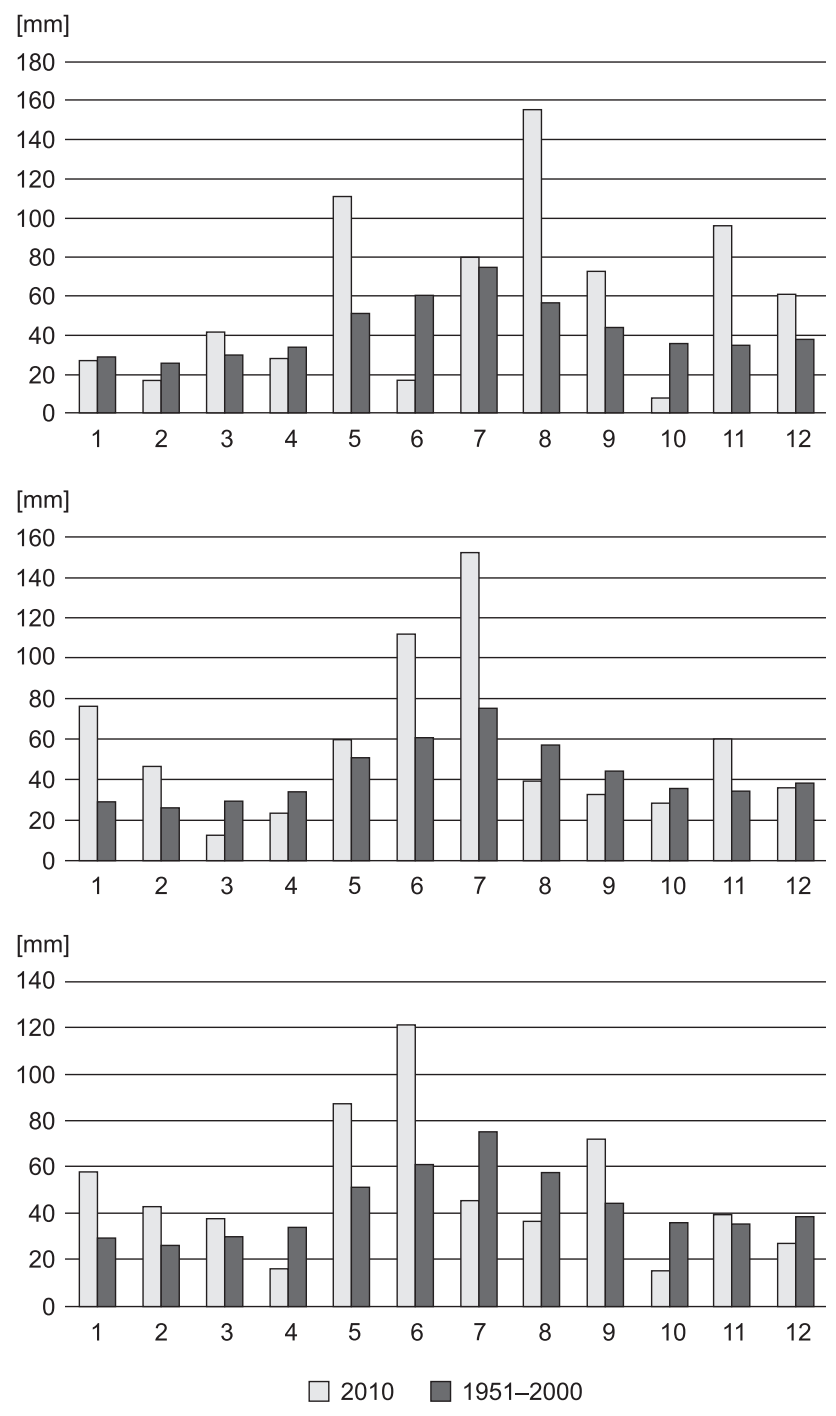

Fig. 3. Accumulated precipitation (mm) - Poznań-Ławica

an effect of prolonged winter. Full leaf development begins in the second half of April, while only in 2013 it was prolonged to the first days of May. Autumn colouration of leaves starts at the end of September and the beginning of October, and full colouration occurs in October and the first decade of November. At that time leaves turn orange or brownish-purple and pear trees are very decorative. Exceptionally in 2013 leaves were slow to change colour and on many trees they had dropped before reaching full autumn colouration. This was probably caused by the relatively high temperatures for that season and a lack of early frost. Leaf fall comes in October and November and the length of this phase varies greatly (10-32 days) in individual years. Leaves in Callery pear remain on trees exceptionally long - even to the end of November, while most deciduous tree species growing in Poznań are leafless already at the turn of October and November. The vegetation cycle of Callery pear in Poznań lasts approx. seven months. Flowering in pears comes in the second half of April and the first half of May. The flowering period is typically rather long, lasting on 


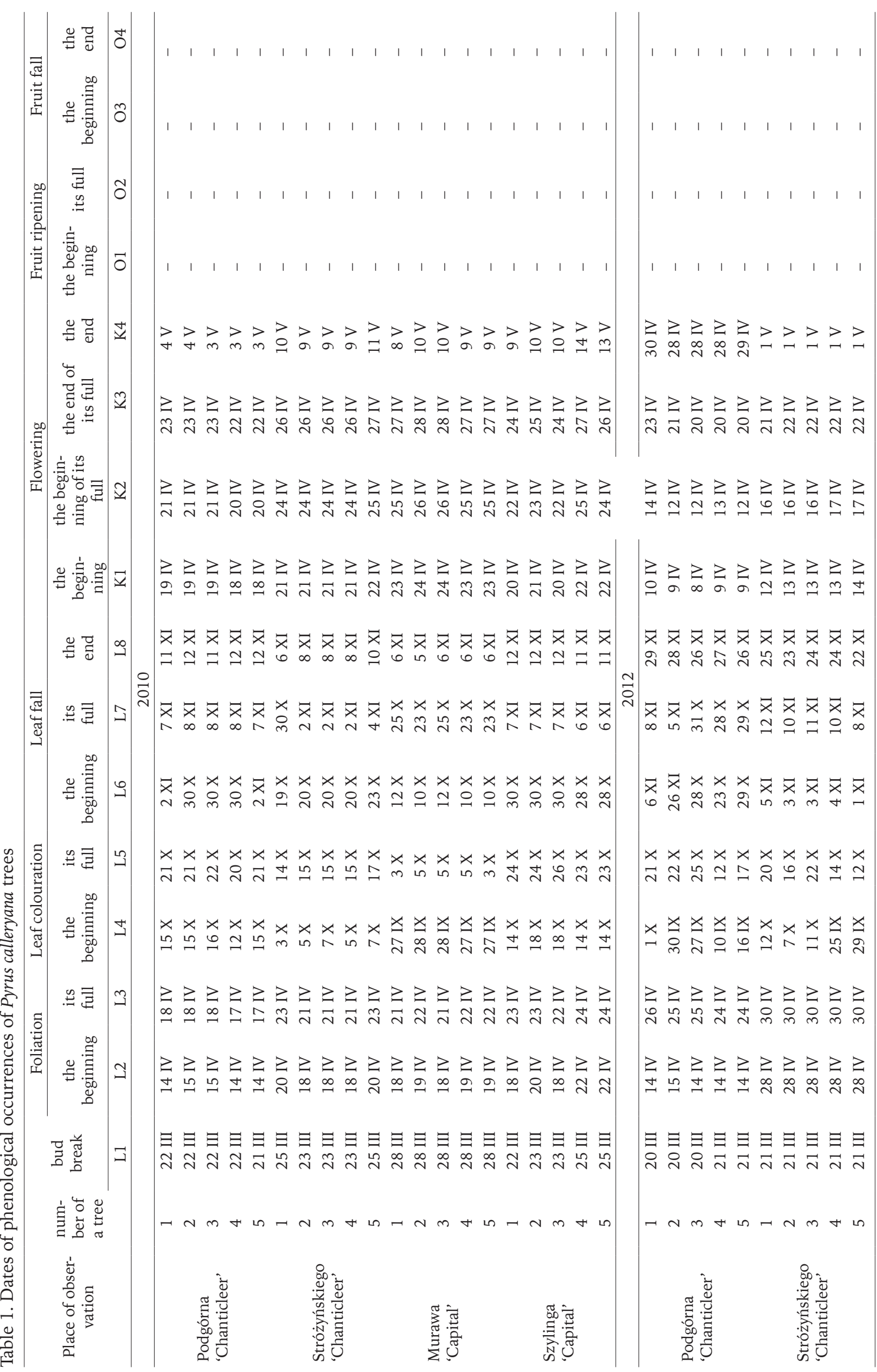




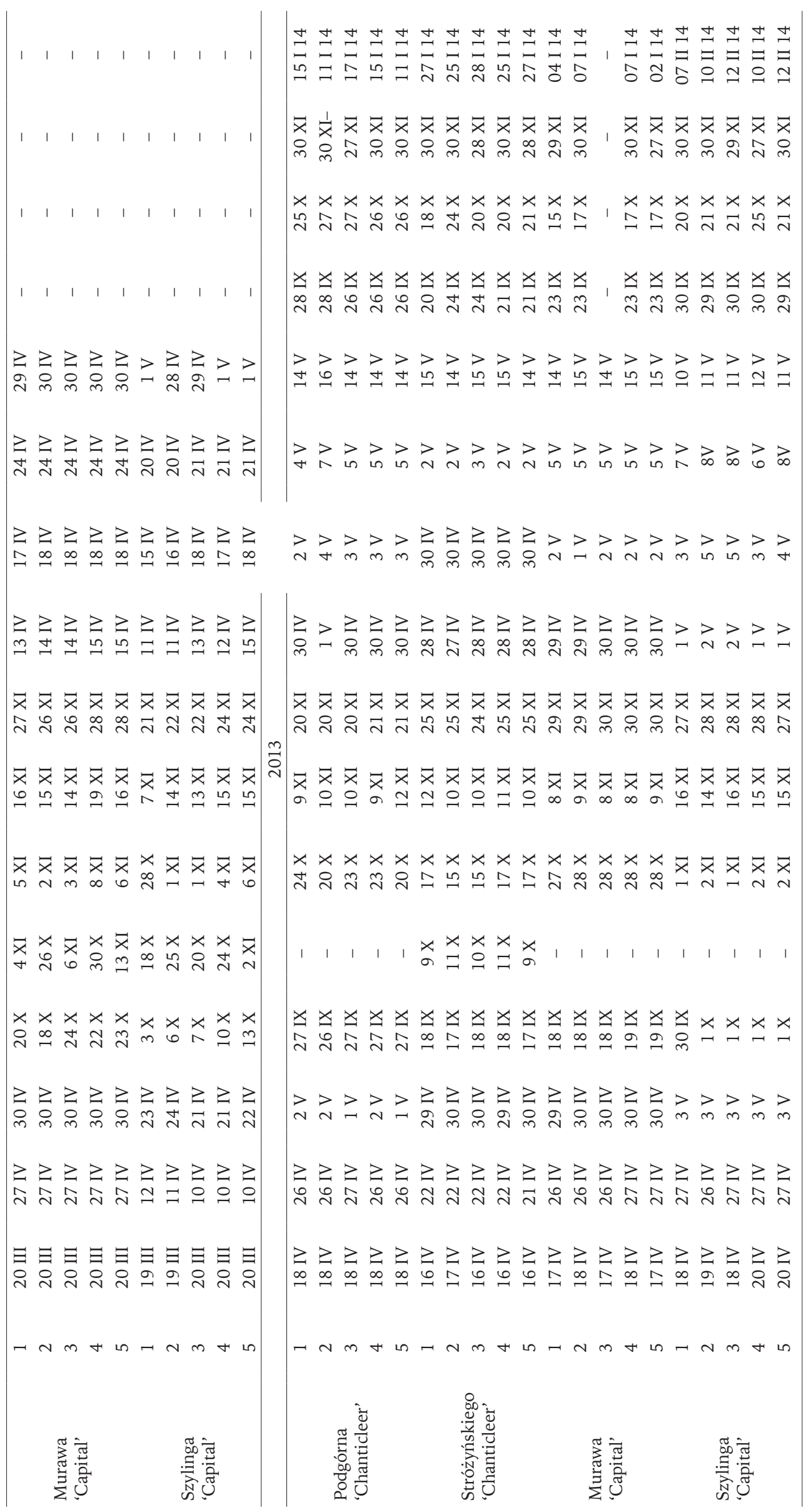


Podgóma 2010

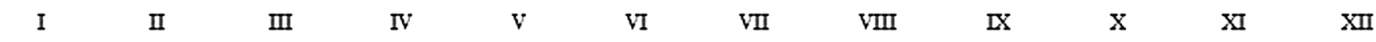
$\begin{array}{llllllllllllllllllllllllllllllllllll}10 & 20 & 31 & 10 & 20 & 28 & 10 & 20 & 31 & 10 & 20 & 30 & 10 & 20 & 31 & 10 & 20 & 30 & 10 & 20 & 31 & 10 & 20 & 31 & 10 & 20 & 30 & 10 & 20 & 31 & 10 & 20 & 30 & 10 & 20 & 31\end{array}$

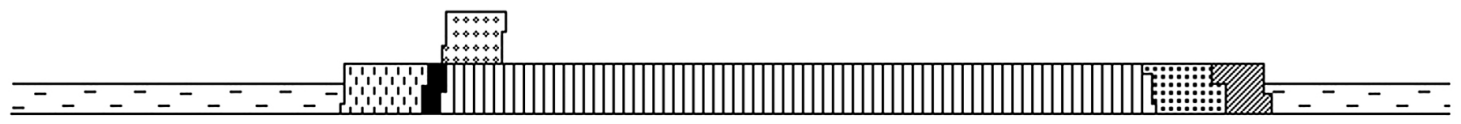

Stróżyńskiego 2010

$\begin{array}{llllllllllll}\text { I II } & \text { III } & \text { IV } & V & \text { VI } & \text { VII } & \text { VIII } & \text { IX } & \text { X } & \text { XI } & \text { XII }\end{array}$

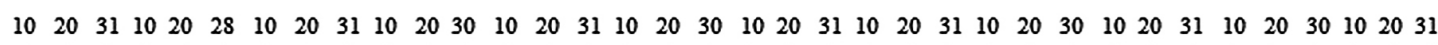

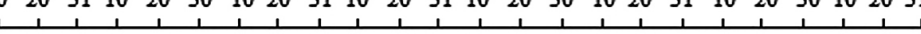

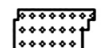

Murawa 2010

$\begin{array}{lllllllllllll}I & \text { II } & \text { III } & \text { IV } & V & \text { VI } & \text { VII } & \text { VIII } & \text { IX } & X & \text { XI } & \text { XII }\end{array}$

$\begin{array}{llllllllllllllllllllllllllllllllllll}10 & 20 & 31 & 10 & 20 & 28 & 10 & 20 & 31 & 10 & 20 & 30 & 10 & 20 & 31 & 10 & 20 & 30 & 10 & 20 & 31 & 10 & 20 & 31 & 10 & 20 & 30 & 10 & 20 & 31 & 10 & 20 & 30 & 10 & 20 & 31\end{array}$

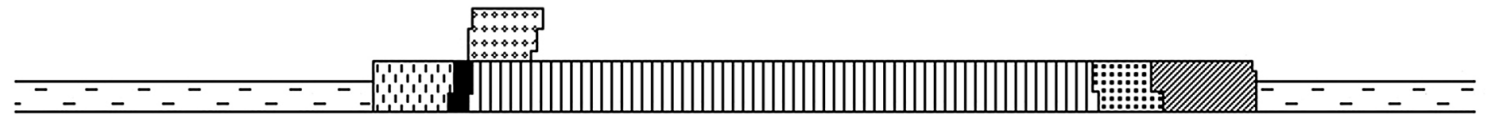

Szylinga 2010

$\begin{array}{lllllllllll}\text { I II } & \text { III } & \text { IV } & V & \text { VI } & \text { VII } & \text { VIII } & \text { IX } & X & \text { XI } & \text { XII }\end{array}$

$\begin{array}{llllllllllllllllllllllllllllllllllll}10 & 20 & 31 & 10 & 20 & 28 & 10 & 20 & 31 & 10 & 20 & 30 & 10 & 20 & 31 & 10 & 20 & 30 & 10 & 20 & 31 & 10 & 20 & 31 & 10 & 20 & 30 & 10 & 20 & 31 & 10 & 20 & 30 & 10 & 20 & 31\end{array}$

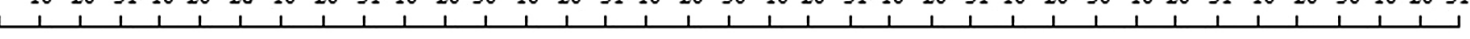
$\sqrt{0.0000009}$

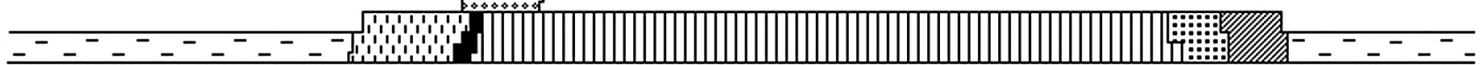

Podgóma 2012

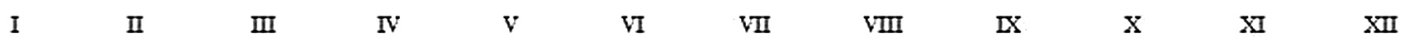

$\begin{array}{llllllllllllllllllllllllllllllllllllllll}10 & 20 & 31 & 10 & 20 & 29 & 10 & 20 & 31 & 10 & 20 & 30 & 10 & 20 & 31 & 10 & 20 & 30 & 10 & 20 & 31 & 10 & 20 & 31 & 10 & 20 & 30 & 10 & 20 & 31 & 10 & 20 & 30 & 10 & 20 & 31\end{array}$

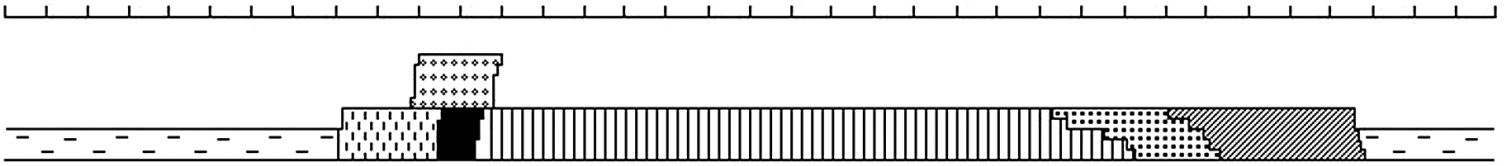

Stróżyńskiego 2012

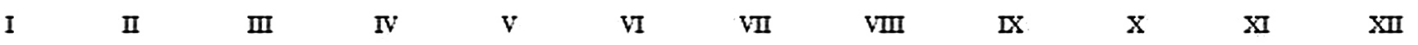

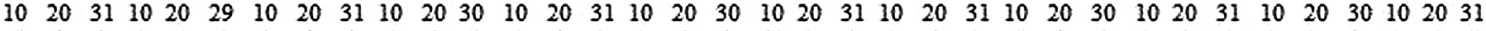

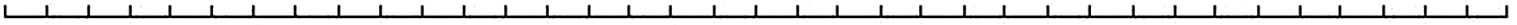


Phenological observations of Callery pear (Pyrus calleryana Decne.) growing in the green areas... 217

Murawa 2012

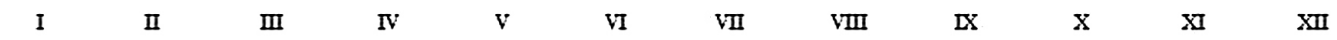

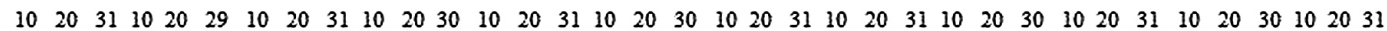

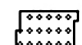

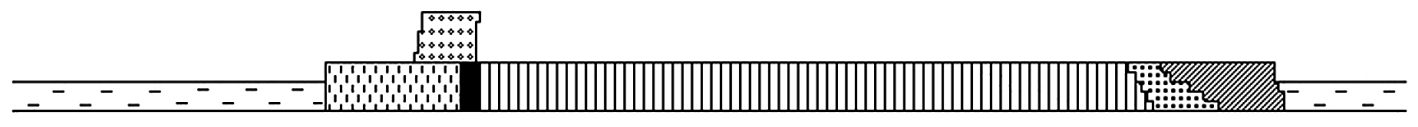

Szylinga 2012

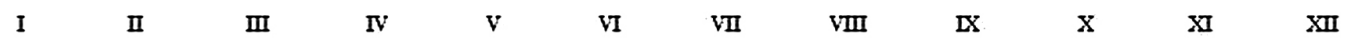

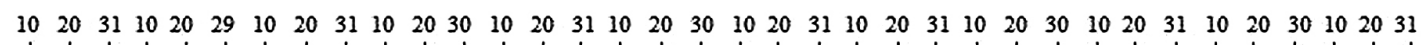

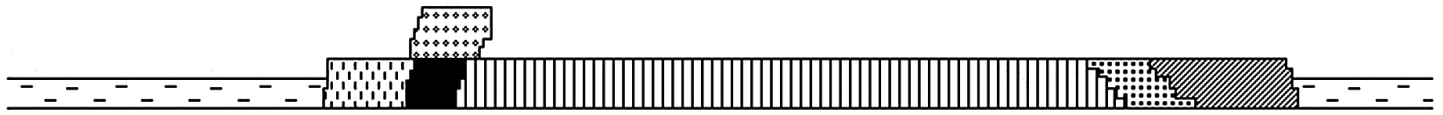

Podgóma 2013

$\begin{array}{lllllllllllll}I & \text { II } & \text { III } & \text { IV } & V & \text { VI } & \text { VII } & \text { VIII } & \text { IX } & X & \text { XI } & \text { XII }\end{array}$

$\begin{array}{llllllllllllllllllllllllllllllllllll}10 & 20 & 31 & 10 & 20 & 28 & 10 & 20 & 31 & 10 & 20 & 30 & 10 & 20 & 31 & 10 & 20 & 30 & 10 & 20 & 31 & 10 & 20 & 31 & 10 & 20 & 30 & 10 & 20 & 31 & 10 & 20 & 30 & 10 & 20 & 31\end{array}$ 1
1

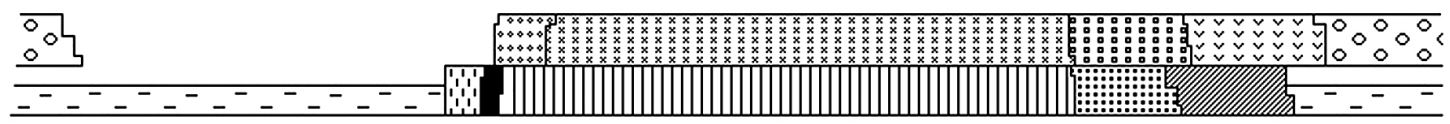

Stróżýnsloiego 2013

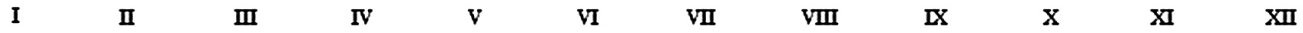

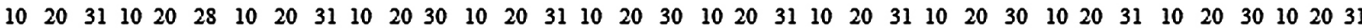

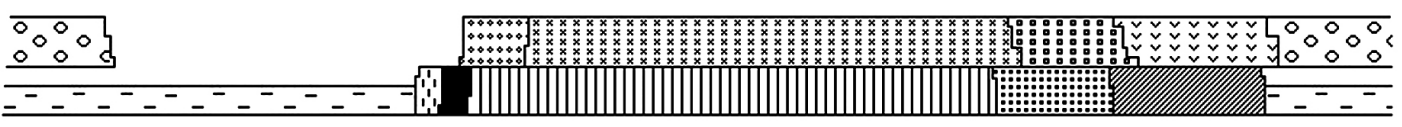

Murawa 2013

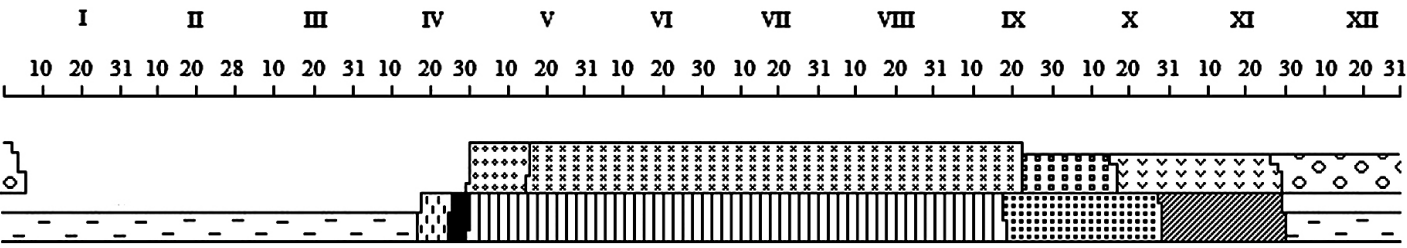

Szylinga 2013

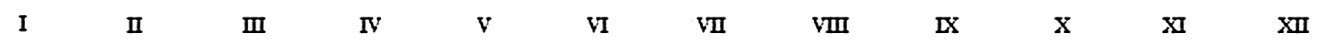

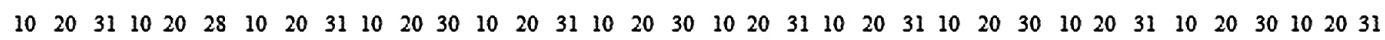

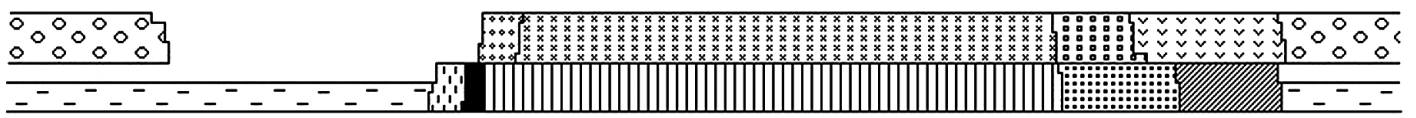

Fig. 4. The course of phenophases of Pyrus calleryana trees in the years 2010, 2012 and 2013 
average 15-19 days. In all the years of observations Callery pears bloomed profusely and in that period trees were most decorative. Fruits of Callery pears are small, they turn brown and are not visually attractive. Practically they become visible only after leaf fall; what is more, they appear relatively rarely. In the 3 -year period of observations fruiting was observed only in 2013, when fruits appeared in greater numbers. In 2010 and 2012 only single fruits were found on trees. Fruit ripening is connected with a change in their colour, in 2013 it started in the last decade of September and full fruit ripening occurred in the second half of October. Fruits of Callery pear remain on trees for very long. In 2013 the beginning of fruit fall was recorded in the last days of November, while the end of fruit fall varied considerably. The end of fruit fall was observed the earliest in trees of cv. 'Capital' - at Murawa street - in the beginning of January in 2014, while it was the latest in trees of the same cultivar growing at Szylinga street - in the first half of February. In the case of trees of cv. 'Chanticleer' the end of fruit fall was recorded in the second and third decade of January.

Differences were observed at dates of onset of successive phenophases in individual years of observations. The most distinct differences were found in the phase of bud burst, defining the onset of vegetation, which in 2013 started on average three weeks later in relation to the earlier years of observations, and the phase of full autumn colouration, which in 2013 was not reached by most trees.

Differences were also observed in dates of onset for individual phenophases at different localities, although it is difficult to indicate a marked regularity in the order of their onsets. These differences could have been influenced by various factors: cultivar, habitat or climatic conditions at individual localities.

\section{DISCUSSION AND RESULTS}

A significant factor in environmental protection and the urban climate is connected with the establishment of green areas and tree plantings along transportation routes (EUKASIEWICZ \& EUKASIEWICZ 2006). In this respect it is important to select tree species resistant to adverse conditions found in cities (EUKASIEWICZ 1978). The need to introduce new species and cultivars of ornamental trees is also stressed to enhance vegetation diversity in urban areas (EUKASIEWICZ \& EUKASIEWICZ 2006). One of the species tolerant to urban conditions, new in Polish municipal green areas, is Callery pear Pyrus calleryana and its cultivars (BOROWSKI \& LATOCHA 2006, LATOCHA 2006, CzeKalski 2010). Phenological observations conducted over a period of several years in Poznań, covering trees of two Callery pear cultivars growing in localities with varied habitat and light conditions located along transportation routes (BEDNORz et al.
2013) showed good adaptation of this species to urban green areas. A long vegetation period, abundant flowering lasting typically for 15-19 days and leaves of attractive autumn colours, remaining on trees for a long time, contribute to the considerable decorative value of Callery pear.

Weather conditions have a significant effect on the course of individual phenological phases of Callery pear. Temperature is the most important climatic factor regulating phenological phenomena. It has a particularly marked effect on the date of bud burst and appearance of the first leaves, while it also determined the duration of the flowering phase. A long, warm autumn and a lack of early frost in 2013 definitely influenced the weak colouration of Callery pear leaves in that year, thus deteriorating the decorative value of trees in that season. Precipitation has a lesser and more limited effect on phenological phases. Differences in the course of individual phenophases in Callery pears on the localities selected for analyses may result from cultivar differences, varying topoclimatic conditions (mainly temperature), as well as habitat and light conditions. In order to assess the effect of the above mentioned factors on the course of individual phenophases it is recommended to considerably increase the number of observed localities within the city. Studies within the proposed extended scope will be continued in the next years.

\section{ACKNOWLEDGEMENTS}

The study was supported by the Department of Botany, Poznań University of Life Sciences.

\section{REFERENCES}

Bednorz L., Adamowicz P., Kowalska A. (2013): Występowanie gruszy drobnoowocowej Pyrus calleryana Decne. w terenach zieleni Poznania. Nauka Przyroda Technologie 7, 4, \#51.

Borowski J. (2012): Dobór drzew, krzewów i pnączy do szczególnie trudnych warunków miejskich. Referat wygłoszony w czasie seminarium Miasto $\mathrm{w}$ zieleni - wyższa jakość życia na 5. Wiosennej Wystawie Szkółkarskiej „Mazowiecka Zieleń 2012 - jakość i asortyment”.

Borowski J., LATocha P. (2006): Dobór drzew i krzewów do warunków przyulicznych Warszawy i miast centralnej Polski. Roczniki Dendrologiczne 54: 83-94.

Bugata W. (1991): Drzewa i krzewy dla terenów zieleni. PWRiL, Warszawa.

Culley T., Hardiman N. (2007): The beginning of a new invasive plant: a history of the ornamental Callery pear in the United States. BioScience 57, 11: 956-964.

Czekalski M. (2010): Drzewa mniej znane. Grusza drobnoowocowa. Zieleń Miejska 5: 28. 
Frazik-ADAmczyк M. (2004): Drzewa małych przestrzeni (cz. 3). Odmiany o koronach stożkowatych lub jajowatych. Szkółkarstwo 3: 61-62.

LAтосна P. (2006): Rośliny ozdobne w architekturze krajobrazu. Cz. 4. Drzewa i krzewy liściaste. Wyd. Hortpress, Warszawa.

ŁUKASIEWICZ A. (1978): Rozwój drzew i krzewów na terenie miasta Poznania. PWN, Poznań.

ŁUKASIEWICZ A., ŁUKASIEWICZ Sz. (2006): Rola i kształtowanie zieleni miejskiej. Wyd. Nauk. UAM, Poznań.

ŁYSIAK G. (2006): Uprawa i odmiany gruszy. Wyd. Hortpress, Warszawa.

Meier U. (1994): Phenological growth stages and identification key of stone fruit. In: U. Meier (ed.). Growth stages of mono- and dicotyledonous plants. BBCH Monograph. Federal Biological Research Centre for Agriculture and Forestry. Blackwell Wissenschafts-Verlag, Berlin. 2nd edition 2001: 52-54.

Swoczyna T., Borowski J., Skalmierska G. (2008): Grusza drobnoowocowa (Pyrus calleryana Decne
'Chanticleer') - nowe drzewo ozdobne w krajobrazie miejskim Warszawy. In: W. Danielewicz (ed.). Dendrologia $\mathrm{w}$ badaniach środowiska przyrodniczego oraz dziedzictwa kulturowego. Materiały Zjazdu Sekcji Dendrologicznej PTB, Szklarska Poręba, 25-27 czerwca 2008. Wyd. Drukarnia PRODRUK, Poznań: 267-273.

Woś A. (2010): Klimat Polski w drugiej połowie XX wieku. Wyd. Nauk. UAM, Poznań.

\section{INTERNET}

Phenological Observation Guide of the IPG (http:// www.agrar.hu-berlin.de/fakultaet/departments/ dntw/agrarmet/phaenologie/ipg/IPG_ObsGuide. pdf)

For citation: Bednorz L., Kowalska A., Grygier N., Kufel U. (2015): Phenological observations of Callery pear (Pyrus calleryana Decne.) growing in the green areas of Poznań. Steciana 19(4): 211219. doi:10.12657/steciana.019.021 